$\xi=-1$

\title{
Integrated Approach to Modeling IC Competence in Students
}

\author{
V.A. Belevitin ${ }^{1}$, S.A. Bogatenkov ${ }^{2}$, V.V. Rudnev ${ }^{1 *}$, M.L. Khasanova ${ }^{1}$, A.I.Tyunin ${ }^{1}$ \\ ${ }^{1}$ South Ural State Humanitarian Pedagogical University, 454074, Russian Federation, Chelyabinsk, Bazhova, 46a, k. 301 \\ ${ }^{2}$ South Ural State University (National Research University),454080, Russia, Chelyabinsk, Lenin Ave., 76 \\ *Corresponding author E-mail: rudnevvv@cspu.ru
}

\begin{abstract}
A strong correlation of the problem of guaranteed information security provision with the human factor and the escalation of threats to information security for professional activity in information society prove the importance of the relevant proper training of highly qualified personnel.

The theoretical justification of the integrated approach to modeling students' information and communication competence (IC competence), including new structure and content of students' preparation under integration of the classical system and e-learning with the development of adequate forms and methods of teaching, promotes the high level of professional competence.

The scope of research is represented by the principles of computational modeling of IC competence, formed as a result of continuous staged personnel training in "Professional Education (by Industries)" based on the Federal State Educational Standard of Russia.

The research offers an integrated approach to computational modeling of students' IC competence based on the classification of competencies demonstrating the projection of a professional competency vector on a plane of information and communication technologies (ICT plane) acting as a model of students' IC competence. Here, any ray of the ICT plane may act as a model of IC competence in a certain specialization of proper training of highly qualified personnel in any industry. Such an approach to IC competence of a graduate of an educational organization is determined by respective aims and fields of professional activity corresponding to IC competencies.

The methodology of content design has been developed for educational disciplines in continuous information and academic training of graduates under e-learning, as well as an algorithm based on the competence approach, making it possible to explicitly determine the generation path of IC competence of professional education organization graduates having different basic training, which eliminates the threat of insufficient or excessive content of the intended study materials.
\end{abstract}

Keywords: personnel training, professional education, classification of competencies, IC competence, e-learning, continuous education.

\section{Introduction}

Over the recent years, industrial disasters and technotronic catastrophes have become more frequent in the world [7]. The problem of providing technogenic safety (TechS), according to the general opinion, is $70 \%$ due to, first of all, professional competence of decision makers in emergency and the human factor [3]. A strong correlation of the problem of providing TechS with the human factor amid the escalation of security threats for professional activity proves the importance of the relevant proper personnel training for working with new information technologies (IT). The need to shape readiness of educational process participants for employment of IT with regard to TechS is now evident. At the same time, topical issues of improvement of specialists' professional training meeting the up-to-date requirements include approaches to modeling students' IC competence engaging functional capabilities of effective means of numerical generation and knowledge transfer, integration methods of diverse information processes in educational activity [4], [8], [9].

Assessment of competencies of young specialists conducted at one of the enterprises of the Ural Mining and Metallurgical Company [6] demonstrated that young engineering technologists showed insufficient capacity for prediction, mechanical intelligence, professional discipline, spatial awareness and combinatory capabilities, skills of dealing with technical documentation, potency for innovation, decision making, as well as their workflow and corpo- rate action management. Among the probable tools complementing each other and making it possible to solve the problem of young engineering technologists training, the following can be mentioned: first, targeted students' training implying additional academic programs, as well as practice and internship at a corporate customer enterprise, and second, e-learning where the teacher acts indirectly employing conventional and innovative methods and means of education based on computer and telecommunication technologies in the educational process.

\section{Purpose and Objectives of the Research}

The purpose of the research is the theoretical justification of the integrated approach to modeling students' IC competence, including new structure and content of student preparation under integration of the classical system and e-learning with the development of adequate forms and methods of teaching, promoting the high level of professional competence.

While planning the research objectives, it has been assumed that the effectiveness of personnel training in the system of continuous professional education will increase if it is conducted in line with the pedagogical conditions diminishing the current inconsistencies: specifically, first of all, a focus on using innovative electronic educational resources meeting the requirements of novelty and significance, focusing the educational process on comprehensive use of the system of conducting academic studies with employ- 
ment of e-learning, which provides effective perception of the material, completion of monitoring activities, and prompts independent learning and understanding activities of students.

The selected field of the research objectives is continuous training in "Professional Education (by Industries)" based on the Federal State Educational Standard of Russia for different levels of professional education. At the same time, methods of professional personnel training design based on the classification of IC competence and modules of disciplines allow planning efficient $\mathrm{e}$ learning educational paths for students having different basic education.

In general case, IC competence represents a multitude of IC competencies, each of them ranked by the following features: aims (general, developmental and professional); character of the competence of professional aims (general and special); fields of educational activity (academic and professional, science and research, education and design); level of education (secondary technical, bachelor, master); training profile.

Let us denote an IC competency as $C_{\text {lap }}$,

where: $l$ is the level of education ( 1 - master of industrial training, 2 - bachelor, 3 - master of professional education); $a$ is the aim or field of activity ( 1 - general, 2 - developmental, 3 - professional, 4 - science and research, 5 - education and design, 6 - organizational and technological, 7 - apprenticeship for a job); $p$ is the educational program specialization ( 0 - for $a=1-5 ; 1-$ economics and management, 2 - power industry, 3 - metallurgy, machinery manufacturing and material processing, $4-$ information and computer science, etc. for $a=6$ and 7).

Such an approach allows representing an IC competency as a projection of the competency vector on an ICT plane acting as a model of the IC competence of students. Here, any ray of the ICT plane may act as a model of IC competence of a certain industry specialization specialist.

Consequently, IC competence of professional education organization (PEO) graduates is determined by corresponding IC competencies of aims and fields of activity. Thus, IC competence of master in professional education specialization "Economics and Management in Metallurgy" will be determined by the formula:

$$
\begin{aligned}
C_{M 01} & =C_{110}+C_{120}+C_{130}+C_{140}+C_{150}+C_{141}+C_{151}+ \\
& +C_{210}+C_{220}+C_{230}+C_{240}+C_{250}+C_{241}+C_{251}+ \\
& +C_{310}+C_{320}+C_{330}+C_{340}+C_{350}+C_{341}+C_{351} .
\end{aligned}
$$

With the purpose of formalization of the problem and its solution according to the principles formulated above, let us define the multitude of information states $Z=\left\{z_{i}\left|z_{i} \in Z, i=1,2, \ldots,\right| Z \mid\right\}$ designating sequential development of the components of IC competencies. Let us assign to each component $z_{i}$ of this multitude a component $y_{m}$ of the multitude of impacts $M$ :

$$
M=\left\{y_{m}\left|y_{m} \in M, m=1,2, \ldots,\right| M \mid\right\} .
$$

In each academic discipline, let us define the multitude:

$$
F_{m}^{(u)}=\left\{f_{m j}^{(u)}\left|f_{m j}^{(u)} \in F_{m}^{(u)}, m=1,2, \ldots,\right| M|, j=1,2, \ldots,| F_{m}^{(u)} \mid\right\}
$$

of the informative features of study signals expressed in different modalities. For the whole aggregate of multitudes $\bigcap_{m=1}^{|M|} F_{m}^{(u)}$ let us define the multitude:

$$
F^{(3)}=\left\{f_{j}^{(3)}\left|f_{j}^{(3)} \in F^{(3)}, j=1,2, \ldots,\right| V \mid\right\}, F^{(3)} \subseteq \bigcap_{m=1}^{|M|} F_{m}^{(u)},
$$

consisting of submultitudes $f_{j}^{(3)}$ of significant informative features of IC competencies explicitly determining the impact of study materials of certain modality (audial, visual, combined, etc.).

Let us present the educational process in general as a formal process of changing the states of the information process $\vec{U}^{(0)}=\left(u_{1}^{(0)}, u_{2}^{(0)}, \ldots, u_{|Z|}^{(0)}\right)$ shaping the components of academic competencies and the process $\vec{U}^{(m)}=\left(u_{1}^{(m)}, u_{2}^{(m)}, \ldots, u_{\left|X^{(r)}\right|}^{(m)}\right)$ of forming educational materials, different in modality, the impact of which significantly influences the expansion of the modal experience of students.

Let us consider the process of formation and classification of IC competencies at the content level. Projection of the professional competency vector on the ICT plane at the content level is equivalent to adding the phrase "with the help of ICT" to the name of the IC competence. Projection of the IC competence vector on the ray of industry specialization "Economics and Management in Metal-

\begin{tabular}{|c|c|}
\hline Bachelor & Master \\
\hline \multicolumn{2}{|l|}{ 1. Professional activity } \\
\hline $\begin{array}{l}\text { Readiness for conducting diagnostic } \\
\text { and prognostic activities for a worker } \\
\text { (specialist) personality development } \\
\text { with the help of ICT (K230) }\end{array}$ & $\begin{array}{l}\text { Ability and readiness to arrange } \\
\text { systems of assessment of teacher } \\
\text { and student activities with the } \\
\text { help of ICT (K330) }\end{array}$ \\
\hline \multicolumn{2}{|l|}{ 2. Scientific and research activity } \\
\hline $\begin{array}{l}\text { Readiness for the search, creation, } \\
\text { distribution, application of novelties } \\
\text { and creativity with the help of ICT } \\
\text { (K240) }\end{array}$ & $\begin{array}{l}\text { Ability and readiness to formu- } \\
\text { late scientific and research objec- } \\
\text { tives, address them with the help } \\
\text { of ICT (K340) }\end{array}$ \\
\hline \multicolumn{2}{|l|}{ 3. Education and design activity } \\
\hline $\begin{array}{l}\text { Readiness for development, analysis } \\
\text { and modification of educational and } \\
\text { program documents for workers } \\
\text { (bachelors, specialists) training with } \\
\text { the help of ICT (K250) }\end{array}$ & $\begin{array}{l}\text { Ability and readiness to design } \\
\text { the educational environment } \\
\text { with the help of ICT (K350) }\end{array}$ \\
\hline \multicolumn{2}{|c|}{ 4. Organizational and technological activity } \\
\hline $\begin{array}{l}\text { Readiness for the organization of } \\
\text { workers (bachelors, specialists) train- } \\
\text { ing in the field of economics and } \\
\text { management in metallurgy with the } \\
\text { help of ICT (K261) }\end{array}$ & $\begin{array}{l}\text { Ability and readiness to manage } \\
\text { workers (bachelors, specialists) } \\
\text { training in the field of economics } \\
\text { and management in metallurgy } \\
\text { with the help of ICT (K361) }\end{array}$ \\
\hline \multicolumn{2}{|l|}{ 5. Apprenticeship for a job } \\
\hline $\begin{array}{l}\text { Readiness for improving labor effi- } \\
\text { ciency and product quality, resource } \\
\text { saving and safety organization in the } \\
\text { field of economics and management } \\
\text { in metallurgy with the help of ICT } \\
\text { (K271) }\end{array}$ & $\begin{array}{l}\text { Ability and readiness to control } \\
\text { students' job performance quali- } \\
\text { ty in the field of economics and } \\
\text { management in metallurgy with } \\
\text { the help of ICT (K371). }\end{array}$ \\
\hline
\end{tabular}
lurgy", in particular, at the content level is equivalent to adding the phrase "in the field of economics and management in metallurgy" to the name of the IC competence. The content of IC competencies is given in Table 1 .

Table 1: Classification of IC competencies for PEO: professional aims

To master each IC competency, a student should learn the respective ICT module and complete academic performance rating tasks for knowledge and skills. ICT modules realizing professional aims of the general division are studied in the context of the following disciplines: methods of professional education $\left(\mathrm{M}_{130}, \mathrm{M}_{250}\right)$, methods of morale building $\left(\mathrm{M}_{230}\right)$, contemporary problems of professional education $\left(\mathrm{M}_{330}\right)$, innovation technologies in science and professional education $\left(\mathbf{M}_{340}\right)$, educational environment design $\left(\mathrm{M}_{340}\right)$. ICT modules realizing professional aims of the special division linked to the industry specialization are studied in the context of elective courses defined by a PEO.

The level rated use of the suggested classification of IC competencies is the factor providing didactic safety at a PEO due to the following reasons:

1. Classification by the aims and character of competence makes it possible to explicitly distribute IC competencies by academic disciplines of the corresponding modules. IC competencies realiz- 
ing general and developmental aims should be viewed in the context of the general cultural module disciplines. In the context of professional disciplines, IC competencies realizing professional aims of general character should be considered, and in the context of elective courses - those realizing professional aims determined by the industry specialization.

2. Classification by the field of activity and levels of PEO allows determining ICT modules of disciplines in which IC competencies will be realized.

3. For students of "Professional Education (by Industries)" in any specialization and having any basic education, there emerged an opportunity of planning the educational path for training PEO graduates according to current employers' demands.

Selection of graded ICT modules based on the competence approach [1], [2], [5] for disciplines where IC competencies of future PEO graduates will be realized in connection with the educational path planned taking into consideration current employers demands, eliminates the threat of insufficient or excessive content of the intended academic materials. In this way, the suggested complex integrated approach to classification of IC competencies for PEO acts to increase the accuracy of computational modeling results for IC competence of students and assessment of their professional competence using interview, analysis of artistic achievements, tests assuring students' professional knowledge compliance to current employers' demands according to qualification grades.

\section{Conclusion}

The conducted integrated research of the process of personnel training for working under e-learning in the system of continuous professional education using computational modeling of students' IC competence as exemplified by graduates training in "Professional Education (by Industries)", including new structure and content of student preparation under integration of the classical system and e-learning with the development of adequate forms and methods of teaching, promotes the high level of professional competence of PEO graduates.

An integrated approach to computational modeling of students' IC competence has been offered, based on the classification of competencies demonstrating projection of a professional competency vector on a plane of information and communication technologies (ICT plane) acting as a model of students' IC competence.

Methodology of content design has been developed for educational disciplines in continuous information and academic training of graduates under e-learning, as well as an algorithm based on the competence approach, making it possible to explicitly determine the generation path of IC competence of PEO graduates having different basic training, which eliminates the threat of insufficient or excessive content of the intended study materials.

\section{References}

[1] Ashanin, A. O. (2015). Formirovanie professionalnoi kompetentnosti budushchego spetsialista $v$ protsesse integratsii obucheniva $i$ vospitaniya [Forming Professional Competence of Future Specialist in the Process of Integration of Education and Morale Building]. Kazan: Institute of Pedagogy and Psychology of Professional Education, $163 \mathrm{p}$.

[2] Bogatenkov, S. A., Gnatyshina, Ye. A., \& Belevitin, V. A. (2017). Kompetentnostno orientirovannoe upravlenie podgotovkoi kadrov $v$ uslovi-yakh elektronnogo obucheniya [Competence Oriented Management of Personnel Training under E-Learning]. Chelyabinsk: South Ural State Humanitarian Pedagogical University Publishing House, $124 \mathrm{p}$.

[3] Bogatenkov, S.A. (2017). Podgotovka personala k rabote s informatsionno-izmeritelnymi sistemami $\mathrm{v}$ aspekte energobezopasnost [Personnel Training for Working with Information and Measurement Systems in the Context of Power Engineering Safety]. Energobezopasnost i energosberezhenie, 1, pp: 34-39.
[4] Brazhnikov, N. I., Belevitin, V. A., \& Brazhnikov, A. I. (2008). Ultrazvukovoi kontrol $i$ regulirovanie tekhnologicheskikh protsessov [Ultrasound Control and Regulation of Technological Processes]. Moscow: Teplotekhnika, $256 \mathrm{p}$.

[5] Domarev, V. V. (2002). Bezopasnost informatsionnykh tekhnologii. Metodologiya sozdaniya sistem [Security of Information Technologies. System Engineering Methodology]. Kiev: OOO "TID "DS", $688 \mathrm{p}$.

[6] Karaman, Ye.V. (2008). Novyi obrazovatelnyi standart: vostrebovan prakticheskii spetsialist [New Educational Standard: Practical Specialist Demanded]. Metallurg, 3, pp: 12-14

[7] Loginov, Ye. L. (2015). Setevye informatsionnye ataki na sistemy upravleniya energeticheskimi obektami kriticheskoi infrastruktury [Network Information Attacks at Systems of Management of Power Facilities of Critical Infrastructure]. Teploenergetika, 4, pp: 3-9.

[8] Minaev, A. A., Smirnov, Ye. N., \& Belevitin, V. A. (1992). O modelirovanii plasticheskogo formoizmeneniya raskatov $\mathrm{s}$ neravnomernym raspredeleniem temperatury po secheniyu na plastilinovykh modelyakh [On Modeling of Plastic Moldability of Rolls with Uneven Temperature Distribution by Cross-Section on Plasticine Models]. Izvestiya vysshikh uchebnykh zavedenii. Chernaya metallurgiya, 4 , pp: 57-59.

[9] Vorontsov, V. K., Belevitin, V. A., \& Brinza, V. V. (1990). Eksperimentalnye metody mekhaniki deformiruemykh tverdykh tel. Tekhnologicheskie zadachi obrabotki davleniem [Experimental Methods in Mechanics of Deformable Solids. Technological Tasks of Pressure Shaping]. Moscow: Metallurgiya, $480 \mathrm{p}$. 